\title{
Chungsim-Yeunja-Tang decreases the inflammatory response in peripheral blood mononuclear cells from patients with cerebral infarction through an NF- $\kappa$ B dependent mechanism
}

Hyun-Ja Jeong ${ }^{1 \dagger}$, In-Young Choi ${ }^{2 \dagger}$, Min-Ho Kim ${ }^{3}$, Hyung-Min Kim² ${ }^{2 *}$ Phil-Dong Moon ${ }^{2}$, Jin-Woo Hong ${ }^{4}$, Soo-Hyun Kim $^{5}$

\begin{abstract}
Background: Chungsim-Yeunja-Tang (CYT) has been used as a medicine for cerebral infarction (Cl) patients in Korea. The objective of this study was to determine precisely the effect of CYT on Cl patients using peripheral blood mononuclear cells (PBMCs).

Methods: For a clinical study, $47 \mathrm{Cl}$ patients were identified who had taken CYT $(0.01 \mathrm{~g} / \mathrm{kg}) 3$ times a day after meals for 2 weeks by oral administration. For ex vivo experiments, peripheral blood mononuclear cells (PBMCs) were isolated from $\mathrm{Cl}$ patients. We analyzed the effect of CYT and its main components on lipopolysaccharide (LPS)-induced cytokine production and mechanism on PBMCS of CI patients by using ELISA, western blot analysis, transcription factor enzyme-linked immunoassay, and caspase assay.

Results: Clinical signs of $\mathrm{Cl}$ significantly disappeared about 2 weeks after oral administration of $\mathrm{CYT}$ to $\mathrm{Cl}$ patients $(P<0.05)$. CYT and quercetin, an active compound of CYT, significantly inhibited LPS-induced interleukin (IL)-1 $\beta$, IL6 , and tumor necrosis factor (TNF)- $\alpha$ production and expression in PBMCs. CYT and quercetin also inhibited LPSinduced nuclear translocation and DNA binding activities of nuclear factor- $\kappa$ B and degradation of $\mid \kappa B \alpha$. In addition, CYT and quercetin inhibited LPS-induced IL-32 expression and caspase-1 activation.

Conclusion: These results suggest a mechanism that might explain the beneficial effect of CYT in treating $\mathrm{Cl}$ patients. Taken together, our findings indicate that inhibition of IL-32 expression and caspase-1 activation may be a novel biomarker and potential therapeutic target in $\mathrm{Cl}$.
\end{abstract}

\section{Background}

Chungsim-Yeunja-Tang (CYT), a traditional Korean medicine, has long been prescribed as a treatment for cerebral infarction $(\mathrm{CI})$ to increase cerebral blood flow and to recover injured brain cells. We have previously reported that CYT regulates the serum level of cytokines in patients with acute CI [1]. However, the effects of

\footnotetext{
* Correspondence: hmkim@khu.ac.kr

+ Contributed equally

${ }^{2}$ Department of Pharmacology, College of Oriental Medicine, Kyung Hee University, 1 Hoegi-dong, Dongdaemun-gu, Seoul, 130-701, Republic of Korea

Full list of author information is available at the end of the article
}

CYT on the regulation of inflammatory cytokine production are still not completely understood. The use of herbal therapies or alternative medicines is becoming an increasingly attractive approach for the treatment of various inflammatory disorders.

Inflammatory processes are orchestrated by inflammatory cells through a complex set of chemical signals and can arise in any tissue in response to traumatic, infectious, post-ischemic, toxic, allergic, or auto-immune injury [2]. In chronic inflammatory diseases, the injury persists and leads to tissue damage [2]. During inflammation, the inflammatory region is infiltrated with 
mononuclear cells, producing a range of inflammatory mediators including inflammatory cytokines [3]. The expression of inflammatory cytokines is dependent on activation of a transcription factor, nuclear factor (NF)$\kappa \mathrm{B}$. Most commonly, NF- $\kappa \mathrm{B}$ dimers are composed of Rel A (p65) and NFKB1 (p50) or NFKB2 (p52) subunits $[4,5]$. NF- $\kappa$ B binds to a specific consensus DNA element present in the promoter region of target genes and initiates transcription of tumor necrosis factor (TNF)- $\alpha$ and interleukin (IL)-6 [6,7]. NF- $\kappa \mathrm{B}$ normally resides in the cytoplasm, where it is retained by association with an I $\kappa \mathrm{B}$ protein $(\alpha, \beta$, or $\gamma)$, an endogenous inhibitor [5]. When activated, it translocates to the nucleus, binds to DNA, and activates genes. This activation involves the phosphorylation, ubiquitination, and degradation of $\mathrm{I} \kappa \mathrm{B}$, leading to the nuclear migration of NF- $\kappa \mathrm{B}[8,9]$. NF- $\kappa \mathrm{B}$ activation via receptor interacting protein -2 has been found to involve caspase-1 [10]. In this case, NF- $\kappa \mathrm{B}$ activation by lipopolysaccharide (LPS) is attenuated in caspase-1-deficient macrophages and is inhibited by a catalytically inactive form of caspase-1 [10].

IL-32, originally named NK cell transcript 4 (NK4), is produced mainly by mitogen-activated lymphocytes, interferon- $\gamma$-activated epithelial cells, IL-12-, IL-18-, and IL-32-activated NK cells; and IL-18 gene-transfected cells [11]. Human IL-32 has six spice variants, IL-32 $\alpha$, IL-32 $\beta$, IL-32 $\gamma$, IL-32 $\delta$, IL-32 $\zeta$, and IL-32 $\varepsilon[12,13]$. Recombinant human IL-32 $\gamma$, the most recently described inflammatory cytokine, stimulates production of IL-1 $\beta$, TNF- $\alpha$, and macrophage inflammatory protein-2 [14]. IL-32 stimulates the secretion of IL-1 $\beta$, IL- 6 , IL- 8 , and TNF- $\alpha$ by activating NF- $\kappa$ B and p38 mitogen-activated protein kinase (MAPK) [12]. In addition, maturation of IL-1 $\beta$ through a caspase-1-dependent mechanism is also a property of IL-32 [14]. IL-32 production is dependent on a proinflammatory pathway involving active IL-18 induced by a caspase-1-dependt pathway [15]. These proinflammatory effects of IL-32 suggest an important role for IL-32 in inflammation.

This paper evaluates the effects of CYT and its main components on LPS-induced cytokine production and expression in peripheral blood mononuclear cells (PBMCs) of CI patients. In order to determine possible mechanisms of the inhibitory actions of CYT, we also investigated its effect on NF- $\kappa \mathrm{B}$ and caspase- 1 activity.

\section{Methods \\ Materials}

Ficoll-Hypaque, LPS, avidin-peroxidase, 3-[4, 5Dimethylthiazole-2-yl]-2, 5,-diphenyl-tetrazolium bromideand (MTT), quercetin, and 2'-azino-bis (3-ethylbenzithiazoline-6-sulfonic acid) tablet substrates (ABTS) were purchased from Sigma (St. Louis, MO, USA). RPMI 1640, ampicillin, streptomycin and fetal bovine serum (FBS) were purchased from Gibco BRL (Grand Island, NY, USA). Anti-human IL-1 $\beta$, TNF- $\alpha$, and IL32 , biotinylated anti-human IL- $1 \beta$ and TNF- $\alpha$, recombinant ( $r$ ) human IL- $1 \beta$ and TNF- $\alpha$, and a caspase- 1 assay kit were purchased from R\&D Systems (Minneapolis, MN, USA). Anti-human IL-6, biotinylated anti-human IL-6, and rhuman IL-6 were purchased from Pharmingen (San Diego, CA, USA). Recombinant IL-32 was purchased from YbdYbiotech (Seoul, Korea)

\section{Subjects}

The subjects of this retrospective study were $47 \mathrm{CI}$ patients (diagnosed by magnetic resonance imager) who had been treated with CYT in Kyung Hee Oriental Medical Center. They were hospitalized within one week of onset, treated for longer than one week, and admitted between March $1^{\text {st }}, 1999$ and February $28^{\text {th }}$, 2001. The 47 CI patients had taken CYT $(0.01 \mathrm{~g} / \mathrm{kg}) 3$ times a day after meals for 2 weeks by oral administration. Thirteen volunteers also participated in PBMC isolation. Blood samples of $\mathrm{CI}$ patients were obtained from the Department of Neurology College of Medicine and Department of Sasang Constitutional Medicine, College of Oriental Medicine, Wonkwang University. All patients had basic tests (blood and urine tests, chest Xray, electrocardiogram) and treatment for ischemic stroke. Informed consent was obtained from all subjects before performing these studies.

\section{PBMC isolation and culture}

PBMCs from heparinized venous blood were isolated with Ficoll gradient centrifugation, washed three times in a phosphate-buffered saline (PBS) solution and resuspended in RPMI 1640 medium (Gibco) supplemented with $2 \mathrm{mM}$ L-glutamine, $100 \mathrm{U} / \mathrm{ml}$ penicillin G, $100 \mu \mathrm{g} / \mathrm{ml}$ streptomycin, and 10\% FBS inactivated for $30 \mathrm{~min}$ at $56^{\circ} \mathrm{C}$. The PBMCs were adjusted to a concentration of $2 \times 10^{6}$ cells $/ \mathrm{ml}$ in a $30 \mathrm{ml}$ falcon tube, and $100 \mu \mathrm{l}$ aliquots of cell suspension were placed in a four-well cell culture plate. The PBMCs were cultured for $24 \mathrm{~h}$ in $95 \%$ humidified air containing $5 \% \mathrm{CO}_{2}\left(37^{\circ} \mathrm{C}\right)$. To determine whether $\mathrm{CYT}$ can modulate LPS-induced IL- $1 \beta$, IL- 6 , and TNF- $\alpha$ production on PBMCs, the cells were pretreated with various concentrations of CYT $(0.01,0.1$, and $1 \mathrm{mg} / \mathrm{ml})$ or quercetin (0.01, 0.1, and $1 \mathrm{mM}$ ) for $2 \mathrm{~h}$ prior to LPS stimulation for $24 \mathrm{~h}$, and the supernatants were collected by centrifugation and stored at $-20^{\circ} \mathrm{C}$.

\section{Preparation of CYT}

The ingredients of $53.3 \mathrm{~g}$ of CYT included $8 \mathrm{~g}$ of Nelumbo nucifera GAERTN, $4 \mathrm{~g}$ of Ophiopogon japonicus KER-GAWL, 8 g of Dioscoreae japonica THUNB, 4 $\mathrm{g}$ of Acorus gramineus SOLAND, $4 \mathrm{~g}$ of Scutellaria 
baicalensis GEORGI, $4 \mathrm{~g}$ of Ziziyphus spinosa HU, $4 \mathrm{~g}$ of Biota orientalis ENDL, $4 \mathrm{~g}$ of Euphoria longan STEUD, $4 \mathrm{~g}$ of Asparagus cochinchinensis MERR, $4 \mathrm{~g}$ of Raphanus sativus L, $4 \mathrm{~g}$ of Polygala tenuifolia WILLD, and $1.3 \mathrm{~g}$ of Chrysanthemum morifolium RAMAT. An extract of CYT was prepared by decocting the dried mixture of herbs with boiling distilled water $(100 \mathrm{~g} / \mathrm{l})$. The decoction was filtered, lyophilized, and kept at $4^{\circ} \mathrm{C}$. The yield of powdered extraction is commonly about $7 \%(\mathrm{w} / \mathrm{w})$. The CYT aqueous extract powder was dissolved in sterile saline $(100 \mathrm{mg} / \mathrm{ml})$ and then filtered using $0.22 \mu \mathrm{m}$ syringe filter. $100 \mathrm{mg} / \mathrm{ml} \mathrm{CYT} \mathrm{was}$ diluted with saline, and we used final concentrations of $0.01,0.1$, and $1 \mathrm{mg} / \mathrm{ml}$ of CYT for the experiments. When the CYT extract was added to medium, it did not precipitate. Quercetin is a component of Nelumbo nucifera GAERTN (approximately 0.36-2.26\%) [16], Biota orientalis ENDL (approximately 1.76\%) [17], Raphanus sativus L (approximately 0.79\%) [18], and Chrysanthemum morifolium RAMAT (approximately 0.05\%) [19]. The dosage of quercetin that is found in CYT (1 mg/ $\mathrm{ml}$ ) was calculated to be about $0.02 \mathrm{mM}$. The plant materials were obtained from Oriental Medicine Hospital, Wonkwang University and identified by J.C. Joo, of the College of Oriental Medicine, Wonkwang University. The voucher specimens (voucher No. 20020427) were deposited in the herbarium in the College of Oriental Medicine at Kyung Hee University.

\section{MTT assay}

The MTT colorimetric assay of cell survival was performed using the method of Ben Trivedi et al., [20] with minor modifications. Cell aliquots $\left(2 \times 10^{5}\right)$ were seeded in microplate wells and incubated with $20 \mu \mathrm{l}$ of a MTT solution $(5 \mathrm{mg} / \mathrm{ml})$ for $4 \mathrm{~h}$ at $37^{\circ} \mathrm{C}$ under $5 \% \mathrm{CO}_{2}$ and 95\% air. Consecutively, $250 \mu \mathrm{l}$ of dimethyl sulfoxide (DMSO) was added to extract the MTT formazan and an automatic microplate reader measured the absorbance of each well at $540 \mathrm{~nm}$.

\section{ELISA of IL-1 $\beta$, IL- 6 , and TNF- $\alpha$}

Cytokine production was measured by a modified sandwich ELISA method, as described previously [21]. ELISA for IL-1 $\beta$, IL-6, and TNF- $\alpha$ was carried out in duplicate in 96-well ELISA plates (Nunc) coated with each of 100 $\mu \mathrm{l}$ aliquots of mouse anti-human IL- $1 \beta$, IL-6, and TNF$\alpha$ monoclonal antibodies at $1.0 \mu \mathrm{g} / \mathrm{ml}$ in $\mathrm{PBS}$ at $\mathrm{pH} 7.4$ and was incubated overnight at $4{ }^{\circ} \mathrm{C}$. The plates were washed in PBS containing 0.05\% Tween-20 (PBST) and blocked with PBS containing 1\% BSA, 5\% sucrose and $0.05 \% \mathrm{NaN}_{3}$ for $1 \mathrm{~h}$. After additional washes, sample or IL- $1 \beta$, IL- 6 , and TNF- $\alpha$ standards were added and incubated at $37^{\circ} \mathrm{C}$ for $2 \mathrm{~h}$. After $2 \mathrm{~h}$ incubation at $37^{\circ} \mathrm{C}$, the wells were washed and then each of $0.2 \mu \mathrm{g} / \mathrm{ml}$ of biotinylated anti-human IL-1 $\beta$, IL- 6 , and TNF- $\alpha$ were added and again incubated at $37^{\circ} \mathrm{C}$ for $2 \mathrm{~h}$. After washing the wells, avidin-peroxidase was added and plates were incubated for $45 \mathrm{~min}$ at $37^{\circ} \mathrm{C}$. Wells were again washed and ABTS substrate (Sigma) was added. Color development was measured at $405 \mathrm{~nm}$ using an automated microplate ELISA reader. A standard curve was run on each assay plate using recombinant human IL$1 \beta$, IL- 6 , and TNF- $\alpha$ in serial dilutions. The inhibition percentage of cytokine production was calculated using the following equation:

$$
\% \text { Inhibition }=\{(c-b)-(s-b)\} \times 100 /(c-b)
$$

where $c$ is LPS-induced cytokine production without CYT and $s$ is LPS+CYT or quercetin-induced cytokine production (b, unstimulated cells).

\section{ELSIA of IL-32}

IL-32 production was measured by direct ELISA method. ELISA for IL-32 was carried out in duplicate in 96-well ELISA plates coated with each of $100 \mu \mathrm{l}$ aliquots of sample or recombinant IL-32 and was incubated overnight at $4{ }^{\circ} \mathrm{C}$. The plates were washed in PBST and blocked with PBS containing 1\% BSA, 5\% sucrose and $0.05 \% \mathrm{NaN}_{3}$ for $1 \mathrm{~h}$. After a $2 \mathrm{~h}$ incubation at $37^{\circ} \mathrm{C}$, the wells were washed and then $0.2 \mu \mathrm{g} / \mathrm{ml}$ of anti-human IL-32 was added and the cells again incubated at $37^{\circ} \mathrm{C}$ for $2 \mathrm{~h}$. After washing the wells, goat horse radish peroxidase conjugated antibody was added and plates were incubated for $45 \mathrm{~min}$ at $37^{\circ} \mathrm{C}$. Wells were again washed and ABTS substrate (Sigma) was added. Color development was measured at $405 \mathrm{~nm}$ using an automated microplate ELISA reader. A standard curve was run on each assay plate using recombinant human IL-32 in serial dilutions.

\section{Reverse-transcriptase polymerase chain reaction (RT-PCR) analysis}

Total RNA was isolated from PBMCs according to the manufacturer's specifications using the Easy-BLUE ${ }^{\mathrm{rm}}$ RNA extraction kit (iNtRON Biotech, Taejeon, Republic of Korea). The concentration of total RNA in the final elutes was determined by spectrophotometry. Total RNA $(1 \mu \mathrm{g})$ was heated at $65^{\circ} \mathrm{C}$ for $10 \mathrm{~min}$ and then chilled on ice. Each sample was reverse-transcribed to cDNA for $90 \mathrm{~min}$ at $37^{\circ} \mathrm{C}$ using a cDNA synthesis kit (Amersham Pharmacia Biotech, Piscataway, NJ, USA). The polymerase chain reaction (PCR) was performed with the following primers for human (h) IL-1 $\beta$ (5 CCG GAT CCA TGG CAC CTG TAC GAT CA 3; 5 GGG GTA CCT TAG GAA GAC ACA AAT TG 3), IL-6 (5 GAT GGA TGC TTC CAA TCT GGA T 3; 5 AGT TCT CCA TAG AGA ACA ACA TA 3), TNF- $\alpha$ 
(5 CGG GAC GTG GAG CTG GCC GAG GAG 3; 5 CAC CAG CTG GTT ATC TCT CAG CTC 3), IL-32 $\gamma$ (5 GTA ATG CTC CTC CCT ACT TC 3; 5 GCA AAG GTG GTG TCA GTA TC 3), and GAPDH (5 CAA AAG GGT CAT CAT CTC TG 3; 5 CCT GCT TCA CCA CCT TCT TG 3) were used to verify that equal amounts of RNA were used for reverse transcription and PCR amplification under different experimental conditions. The annealing temperature was $50^{\circ} \mathrm{C}$ for IL$1 \beta, 56^{\circ} \mathrm{C}$ for IL- $6,60^{\circ} \mathrm{C}$ for TNF- $\alpha, 59^{\circ} \mathrm{C}$ for IL- $32 \gamma$, and $62^{\circ} \mathrm{C}$ for $\mathrm{GAPDH}$, respectively. Products were electrophoresed on a $1.5 \%$ agarose gel and visualized by staining with ethidium bromide.

\section{Nuclear protein extraction}

Crude nuclear extract was isolated from cells. After cell activation for the times indicated, cells were washed in $1 \mathrm{ml}$ of ice-cold PBS, centrifuged at $1000 \times \mathrm{g}$ for $5 \mathrm{~min}$ utes, resuspended in $400 \mu \mathrm{l}$ of ice-cold hypotonic buffer (10 mM HEPES/KOH, $2 \mathrm{mM} \mathrm{MgCl}_{2}, 0.1 \mathrm{mM}$ EDTA, 10 $\mathrm{mM} \mathrm{KCl}, 1 \mathrm{mM}$ DTT, O.5 mM PMSF, pH 7.9), left on ice for 10 minutes, vortexed, and centrifuged at 15,000 $\times \mathrm{g}$ for $30 \mathrm{~s}$. Pelleted nuclei were gently resuspended in $50 \mu \mathrm{l}$ of ice-cold saline buffer (50 mM HEPES/KOH, 50 mM KCl, $300 \mathrm{mM} \mathrm{NaCl}, 0.1 \mathrm{mM}$ EDTA, 10\% glycerol, $1 \mathrm{mM}$ DTT, $0.5 \mathrm{mM}$ PMSF, pH 7.9), left on ice for 20 min, vortexed, and centrifuged at $15,000 \times \mathrm{g}$ for $5 \mathrm{~min}$ at $4^{\circ} \mathrm{C}$. Aliquots of the supernatant, which contained nuclear proteins, were frozen in liquid nitrogen and stored at $-70^{\circ} \mathrm{C}$. Protein was determined using a Bicinchoninic acid protein assay method (Sigma, St. Louis, MO, USA).

\section{Western blot analysis}

Cell extracts were prepared by detergent lysis procedure. Cells $\left(2 \times 10^{6}\right.$ cells $)$ were scraped, washed once with PBS, and resuspended in lysis buffer. Samples were vortexed for lysis for a few seconds every $15 \mathrm{~min}$ at $4^{\circ} \mathrm{C}$ for $1 \mathrm{~h}$ and centrifuged at $15,000 \times \mathrm{g}$ for $5 \mathrm{~min}$ at $4^{\circ} \mathrm{C}$. Supernatants were assayed. Samples were heated at $95^{\circ} \mathrm{C}$ for $5 \mathrm{~min}$, and briefly cooled on ice. Following the centrifugation at $15,000 \times \mathrm{g}$ for $5 \mathrm{~min}, 50 \mu \mathrm{g}$ aliquots were resolved by $10 \%$ SDS-PAGE. Resolved proteins were electrotransferred overnight to nitrocellulose membranes

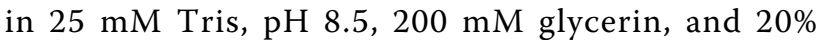
methanol at $25 \mathrm{~V}$. Blots were blocked for at least $2 \mathrm{~h}$ with $1 \times$ PBST containing 5\% nonfat dry milk. Protein levels were analyzed essentially according to the manufacturer's instructions.

Transcription factor enzyme-linked immunoassay (TF-EIA) Avidin peroxidase was coated on a 96-well ELISA plate. The coated plate was washed with PBST and then blocked with a $3 \%$ skim milk solution. The coated plate was incubated with $1 \mu \mathrm{g} / \mathrm{ml}$ of 5'-biotinylated 21 single strand DNA oligonucleotide sequence for $1 \mathrm{~h}$ at room temperature. This sequence contains the previously described NF- $\kappa$ B binding motif. The sequences used here were: 5 AGT TGA GGG GAC TTT CCC AGG 3. A DNA-binding reaction was carried out in a total volume $100 \mu \mathrm{l}$ containing $10 \mu \mathrm{g}$ nuclear protein extract in a buffer containing $10 \mathrm{mM}$ HEPES (pH 7.9), $50 \mathrm{mM}$ $\mathrm{NaCl}, 5 \%$ glycerol, $1 \mathrm{mM}$ EDTA, and $1 \mathrm{mM}$ DTT, for 1 $\mathrm{h}$ at room temperature and then washed. NF- $\kappa \mathrm{B}$ antibodies were then added at a 1:500 concentration in PBS containing 3\% BSA for $1 \mathrm{~h}$, followed by the addition of the corresponding alkaline phosphatase (AP)-coupled secondary antibody. Between each addition, the wells were extensively washed in PBST. AP activity was then detected by the addition of p-nitrophenyl phosphate (PNPP) solution (Sigma). After a 10-min incubation period, the reaction was arrested by the addition of $0.5 \mathrm{M}$ $\mathrm{H}_{2} \mathrm{SO}_{4}$, Color intensity was detected at $405 \mathrm{~nm}$ using ELISA reader. AP activity was normalized to control values (unstimulated cells).

\section{Statistical analysis}

Statistical differences between the groups were estimated using an ANOVA with a Tukey post hoc test and Mann-Whitney $U$-test. The results were considered significant at a value of $P<0.05$.

\section{Results}

\section{Effect of CYT on $\mathrm{Cl}$ patients}

Subjects included in this study were 47 patients. Table 1 shows the general characteristics of the study group. We compared the scores of NIH stroke scale (NIHSS),

Table 1 Baseline characteristics of the study subjects

\begin{tabular}{lc}
\hline Characteristic & $\begin{array}{c}\text { CYT Medication } \\
\text { (N = 47) }\end{array}$ \\
\hline Female sex, n (\%) & $30(64)$ \\
Age, year (SD) & $62.9(13.9)$ \\
Time since stroke, day (SD) & $2.1(1.6)$ \\
Admitting day (SD) & $24.7(18.4)$ \\
Medical history & \\
$\quad$ Hypertension, n (\%) & $26(55)$ \\
$\quad$ Diabetes Mellitus, n (\%) & $10(21)$ \\
Social history & $14(30)$ \\
$\quad$ Smoking, n(\%) & $16(34)$ \\
$\quad$ Alcohol, n(\%) & $3.8(1.5)$ \\
Motor grade (upper limb) (SD) & $3.8(1.4)$ \\
Motor grade (lower limb) (SD) & $3.6(4.1)$ \\
NIH Stroke Scale (SD) & $72.4(32.9)$ \\
Modified Barthel Index (SD) &
\end{tabular}

CYT, Chungsim-Yeunja-Tang; SD, standard deviation; FBS, fasting blood sugar; LDL-c, low density lipoprotein cholesterol. CYT was administrated orally for 2 weeks. 
Modified Barthel Index (MBI), motor grade (upper limb), and motor grade (lower limb) between admission and discharge date. Discharge date scores $(\mathrm{N}=47)$ of $\mathrm{MBI}$, motor grade (upper limb), and motor grade (upper limb) were significantly higher than those from the admission date $(P=0.040,0.030$, and 0.011 , respectively), but there was no significant difference in NIHSS scores $(P=0.086)$ (Table 2$)$.

\section{Effect of CYT on LPS-induced cytokine production by PBMCs}

To determine whether CYT can modulate LPS-induced IL-1 $\beta$, IL- 6 , and TNF- $\alpha$ production in PBMCs, the cells were pretreated with various concentrations of CYT (0.01, 0.1 , and $1 \mathrm{mg} / \mathrm{ml})$ for $2 \mathrm{~h}$ prior to LPS stimulation for $24 \mathrm{~h}$. Culture supernatants were assayed for IL-1 $\beta$, IL- 6 , and TNF- $\alpha$ protein levels by ELISA method. LPS $(10 \mathrm{ng} / \mathrm{ml})$ increased cytokine production in the PBMCs. However, in LPS-stimulated cells, IL-1 $\beta$, IL-6, and TNF- $\alpha$ production was decreased by treatment of CYT (about $183 \pm 11.4 \%$ for IL-1 $\beta, 82.3 \pm 12 \%$ for IL-6, and $71.4 \pm 4.4 \%$ for TNF- $\alpha$ at $1 \mathrm{mg} / \mathrm{ml}, P<0.05)$. CYT inhibited LPS-induced IL-1 $\beta$, IL- 6 , and TNF- $\alpha$ production in a dose-dependent manner (Figure 1). Cell cytotoxicity of CYT was not observed (data not shown).

\section{Effect of components of CYT on LPS-induced cytokine production on PBMCs}

To determine whether quercetin, hyperoside (a component of Nelumbo nucifera GAERTN), or baicalein (a component of Scutellaria baicalensis GEORGI) can modulate LPS-induced IL-1 $\beta$, IL- 6 , and TNF- $\alpha$ production on PBMCs, the cells were pretreated with various concentrations of quercetin $(0.01,0.1$, and $1 \mathrm{mM})$, hyperoside $(0.01,0.1$, and $1 \mathrm{mM})$, or baicalein $(0.01,0.1$, and $1 \mathrm{mM}$ ) for $2 \mathrm{~h}$ prior to LPS stimulation for $24 \mathrm{~h}$. Culture supernatants were assayed for IL-1 $\beta$, IL-6, and TNF- $\alpha$ protein levels by ELISA method. Quercetin inhibited LPS-induced IL- $1 \beta$, IL- 6 , and TNF- $\alpha$ production (about $103.7 \%$ for IL-1 $\beta, 100.5 \%$ for IL- 6 , and $102.8 \%$ for TNF- $\alpha$ at $0.1 \mathrm{mM}, P<0.01$, Figure 2 ). The

Table 2 Changes of NIHSS, MBI, and motor grade of CYT medication group

\begin{tabular}{cccc}
\hline & baseline & after 2weeks & \\
\cline { 2 - 3 } Items & Mean & Mean & $\boldsymbol{P}^{*}$ \\
\hline NIHSS & $3.6 \pm 4.1$ & $2.0 \pm 2.3$ & 0.086 \\
\cline { 2 - 3 } MBI & $72.4 \pm 32.9$ & $86.8 \pm 18.7$ & 0.040 \\
\cline { 2 - 3 } $\begin{array}{c}\text { Motor grade } \\
\text { (upper limb) } \\
\text { Motor grade } \\
\text { (lower limb) }\end{array}$ & $3.8 \pm 1.5$ & $4.2 \pm 1.0$ & 0.030 \\
\cline { 2 - 3 } & $3.8 \pm 1.4$ & $4.3 \pm 0.8$ & 0.011 \\
\hline
\end{tabular}

CYT, Chungsim-Yeunja-Tang; NIHSS, NIH stroke scale; MBI, Modified Barthel Index. $\mathrm{N}=47$. estimated $\mathrm{IC}_{50}$ values of IL- $1 \beta$, IL- 6 , and TNF- $\alpha$ production were about $0.009,0.046$, and $0.007 \mathrm{mM}$, respectively. Cell cytotoxicity of quercetin at concentrations of 0.01 and $0.1 \mathrm{mM}$ was not observed (data not shown) but $1 \mathrm{mM}$ quercetin does show cell cytotoxicity. Hyperoside and baicalein did not affect LPS-induced inflammatory cytokine production (data not shown).

\section{Effects of CYT and quercetin on LPS-induced cytokine mRNA expression in PBMCs}

To determine whether CYT can modulate LPS-induced cytokine expression, cells were pretreated with CYT or quercetin for $2 \mathrm{~h}$ prior to LPS stimulation. We performed the RT-PCR analysis for IL-1 $\beta$, IL- 6 , and TNF$\alpha$ at $8 \mathrm{~h}$. mRNA expression was up-regulated by LPS but the up-regulated IL- $1 \beta$, IL- 6 , and TNF- $\alpha$ mRNA expression was decreased by treatment with CYT $(1 \mathrm{mg} / \mathrm{ml})$ or quercetin (0.1 mM) (Figure 3$)$.

\section{Effects of CYT and quercetin on LPS-induced NF- $\kappa$ B activation}

The expression of inflammatory cytokines is regulated by the transcription factor, nuclear factor (NF)- $\kappa \mathrm{B} / \mathrm{Rel}$ $[6,7]$. Expression levels of NF- $\kappa \mathrm{B} / \operatorname{Rel} A(\mathrm{p} 65)$ in the nucleus and cytoplasm of PBMCs was examined using western blot analysis. In LPS-stimulated cells, the expression level of NF- $\kappa \mathrm{B}$ (p65) declined in the cytoplasm and concurrently increased in the nucleus. However, the expression level of NF- $\kappa \mathrm{B}$ (p65) in the nucleus decreased by treatment with CYT or quercetin (Figure 4A). We also investigated the effect of CYT on LPSinduced NF- $\kappa \mathrm{B}$ transcription complex. To perform these studies, we used an NF- $\kappa \mathrm{B}$ TF-EIA method. This assay has the advantage of being 10 times more sensitive than an electrophoretic mobility shift assay, and it allows greater flexibility in the experimental step. As shown in Figure 4B, LPS increased DNA-binding activity for NF$\kappa \mathrm{B}$, but this increased binding activity was decreased by treatment with CYT $(1 \mathrm{mg} / \mathrm{ml})$ or quercetin $(0.1 \mathrm{mM})$. Activation of NF- $\kappa \mathrm{B}$ required phosphorylation and proteolytic degradation of the inhibitory protein $\mathrm{I} \kappa \mathrm{B} \alpha$. To determine whether the inhibitory action of CYT was due to the effect on $\mathrm{I} \kappa \mathrm{B} \alpha$ degradation, cytoplasmic levels of $\mathrm{I} \kappa \mathrm{B} \alpha$ protein were examined after LPS-stimulation using a western blot analysis. CYT or quercetin also decreased degradation of $\mathrm{I} \kappa \mathrm{B} \alpha$ (Figure $4 \mathrm{C}$ ). Neither $\beta$-actin nor histone expression levels in the nucleus or cytosol extracts changed with either treatment.

\section{Effects of CYT and quercetin on LPS-induced IL-32 expression in PBMCs}

IL-32 stimulates the secretion of inflammatory cytokines by activating NF- $\kappa \mathrm{B}$ [12]. To determine whether CYT or quercetin can modulate LPS-induced IL-32 

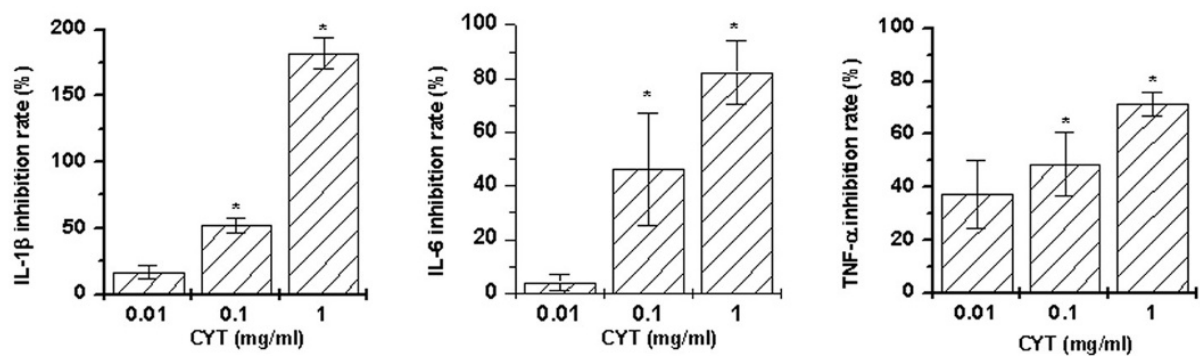

Figure 1 Effect of CYT on LPS-induced cytokine production. Peripheral blood mononuclear cells (PBMCs) $\left(2 \times 10^{5}\right)$ were treated with various concentrations of Chungsim-Yeunja-Tang (CYT) for $2 \mathrm{~h}$ and then stimulated with LPS (10 ng/ml) for $24 \mathrm{~h}$. Cytokine concentrations were measured in cell supernatants using the ELISA method. Data shown are the inhibition rate \pm S.D. for 10 donors, measured in duplicate. ${ }^{*} P<$ 0.05 , significantly different from the unstimulated cells. ${ }^{*} P<0.05$ compared to LPS alone.

production by PBMCs, the cells were pretreated with various concentrations of CYT $(0.01,0.1$, and $1 \mathrm{mg} / \mathrm{ml})$, quercetin $(0.01$ and $0.1 \mathrm{mM})$ or caspase- 1 inhibitor (10 $\mu \mathrm{M})$ for $2 \mathrm{~h}$ prior to LPS stimulation for $24 \mathrm{~h}$. Culture supernatants were assayed for IL-32 protein levels by the ELISA method. CYT, quercetin, and caspase- 1 inhibitor all significantly inhibited LPS-induced IL-32 production (Figure 5A). To determine whether CYT or quercetin can modulate LPS-induced IL-32 mRNA expression, cells were pretreated with CYT or quercetin for $2 \mathrm{~h}$ prior to LPS stimulation. As shown in Figure 5B, mRNA expression was up-regulated by LPS, but the upregulation decreased with CYT $(1 \mathrm{mg} / \mathrm{ml})$ and quercetin $(0.1 \mathrm{mM})$ treatments.

\section{Effects of CYT and quercetin on LPS-induced caspase-1 activation}

Caspase- 1 is activated in a variety of inflammatory responses; caspase- 1 was activated by treatment with LPS [15]. We investigated the inflammatory pathway involving caspase-1. To determine if CYT or quercetin inhibits caspase- 1 activation induced by LPS, cells were exposed to LPS in the presence or absence of CYT (1 $\mathrm{mg} / \mathrm{ml}$ ) or quercetin $(0.1 \mathrm{mM})$. Extracts prepared from PBMCs exposed to LPS contained strong caspase-1 activity compared with unstimulated cells. As shown in Figure 6A, increased caspase-1 activity was significantly inhibited by treatment with CYT or quercetin $(P<$ $0.05)$. Caspase- 1 is present in cells as an inactive zymogen and is activated by LPS treatment. The activation of caspase- 1 plays an important role in NF- $\kappa \mathrm{B}$ activation and IL-32 production $[10,15]$. Caspase-1 precursor protein was evaluated by western blot analysis. Western blot analysis indicates that LPS treatment induced degradation of caspase-1 precursor, which was inhibited by treatment CYT or quercetin (Figure 6B).

\section{Discussion}

Herbal remedies and botanicals are widely used by humans for both preventative and curative purposes.
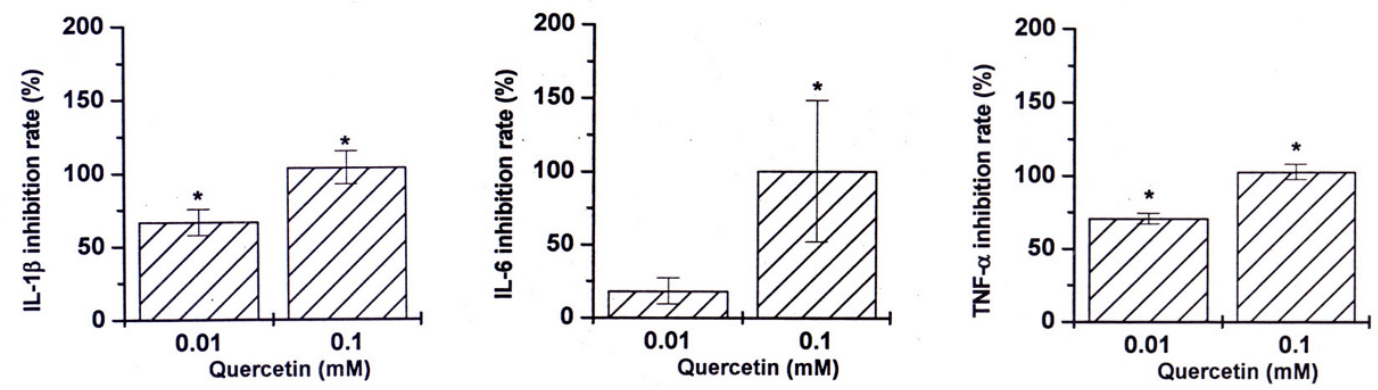

Figure 2 Effect of quercetin on LPS-induced cytokine production. PBMCs $\left(2 \times 10^{5}\right)$ were treated with various concentrations of quercetin for $2 \mathrm{~h}$ and then stimulated with LPS $(10 \mathrm{ng} / \mathrm{ml})$ for $24 \mathrm{~h}$. Cytokine concentrations were measured in cell supernatants using the ELISA method. Data shown are the inhibition rate \pm S.D. for 10 donors, measured in duplicate. ${ }^{*} P<0.05$, significantly different from the unstimulated cells. ${ }^{*} P$ $<0.05$ compared to LPS alone. 


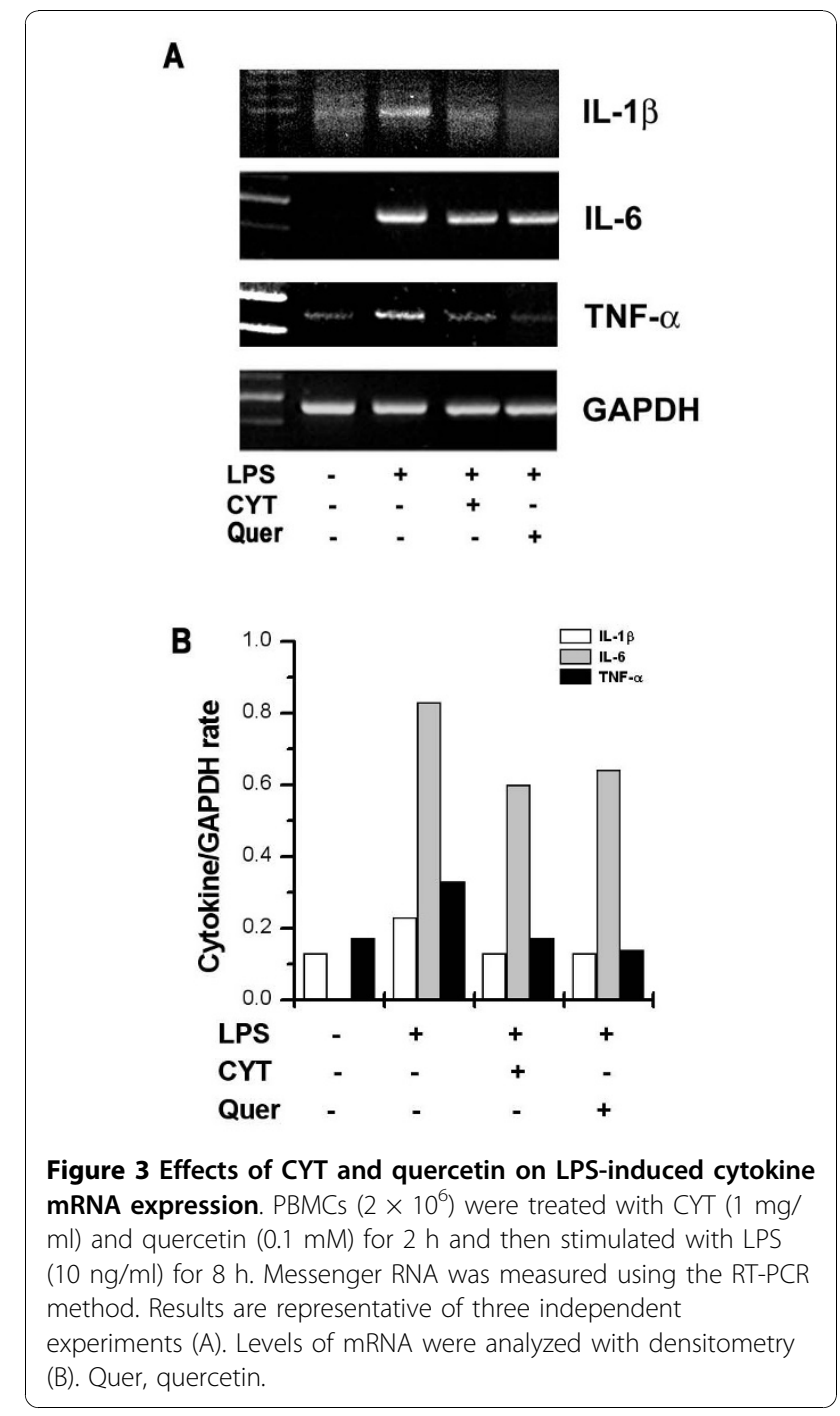

Traditional medicinal herbs have many benefits, few (if any) side effects, and display low cytotoxicity, and so the search for the use of natural products in traditional medicine is currently attracting intense interest. In previous studies, we have investigated the effects of various traditional medicines (Yulda-Hanso-Tang, Gigukjiwhangwhan-gami, Seogak Jihwag-Tang, Jeo Dang-Tang, and Yangkyuk-Sanhwa-Tang) in patients with CI. We reported that Th2 cytokine (IL-1 $\beta$, IL-4, and IL-6) levels are higher than Th1 cytokine (IL-2 and IFN- $\gamma$ ) levels in patients during the acute stage of $\mathrm{CI}$ and that traditional medicines regulate the Th1/Th2 cytokine unbalance in patients with CI [22]. As part of our continuing search for biologically active anti-inflammatory agents from oriental medicines, we investigated CYT. As described above, CYT consists of 12 different herbs. Our previous studies showed that an aqueous extract of Asparagus cochinchinensis inhibits the secretion of TNF- $\alpha$ from
A

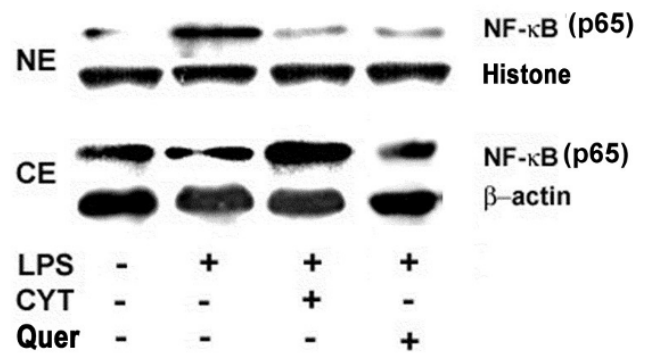

B

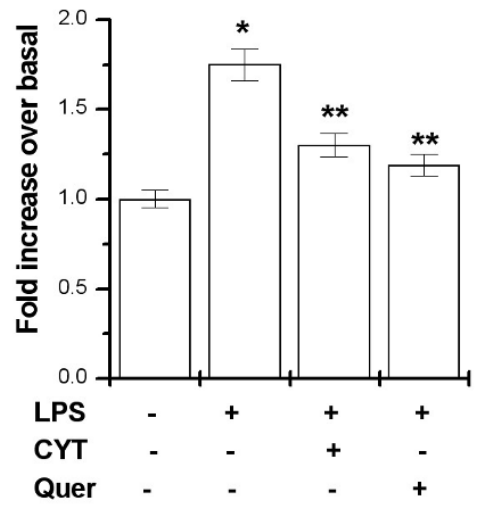

C

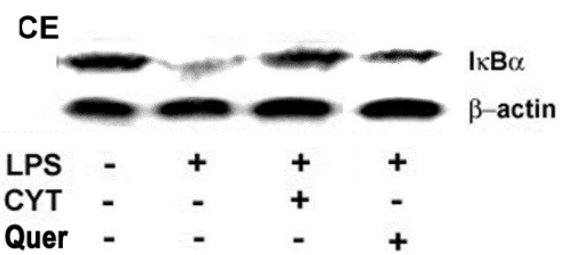

Figure 4 Effects of CYT and quercetin on LPS-induced NF- $\kappa$ B activation and $\mathrm{I} \kappa \mathrm{B}$ degradation. PBMCs $\left(2 \times 10^{6}\right)$ were treated with CYT $(1 \mathrm{mg} / \mathrm{ml})$ and quercetin $(0.1 \mathrm{mM})$ for $2 \mathrm{~h}$ and then stimulated with LPS $(10 \mathrm{ng} / \mathrm{ml})$ for $6 \mathrm{~h}$. Nuclear and cytoplasmic protein was prepared and analyzed for $\mathrm{NF}-\kappa \mathrm{B}$ and $\mathrm{I} \kappa \mathrm{B} \alpha$ by western blotting as described in the experimental procedures ( $\mathrm{A}$ and $\mathrm{C}$ ). Nuclear protein was incubated in a 96-well plate coated with an oligonucleotide containing the NF- $\kappa \mathrm{B}$ binding site. Presence of NF$\kappa \mathrm{B}$ transcription complex was evaluated with an $\mathrm{NF}-\kappa \mathrm{B}$ antibody. Results are expressed as the fold increases of absorbance at $405 \mathrm{~nm}$ over control conditions (B). Results are representative of three independent experiments. ${ }^{*} P<0.05$, significantly different from the unstimulated cells. ${ }^{* *} P<0.05$ compared to LPS alone. NE, nuclear extract; $C E$, cytosol extract; Quer, quercetin.

primary cultures of mouse astrocytes [23] and Hep G2 cells [24]. It has been reported that a fructan, Opaw-2, isolated from Ophiopogon japonicus, stimulates proliferation of cultured lymphocytes [25]. Extracts from Nelumbo Nucifera suppress cell cycle progression, cytokine gene expression, cell proliferation, and inflammatory reactions $[26,27]$. Zhang et al. [28] reported that an 
A

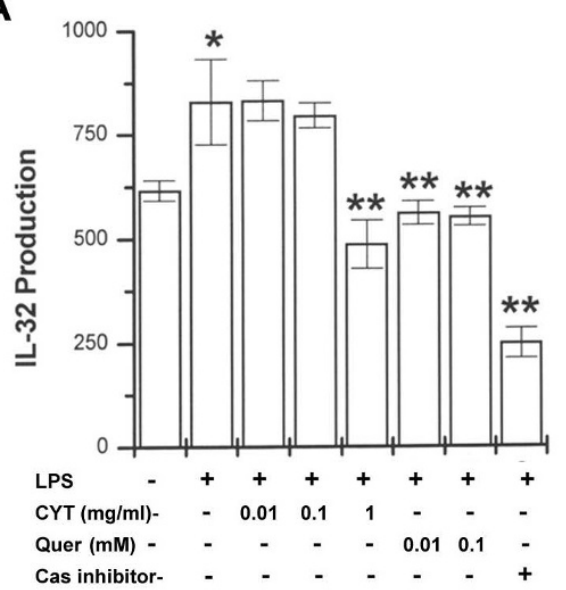

B
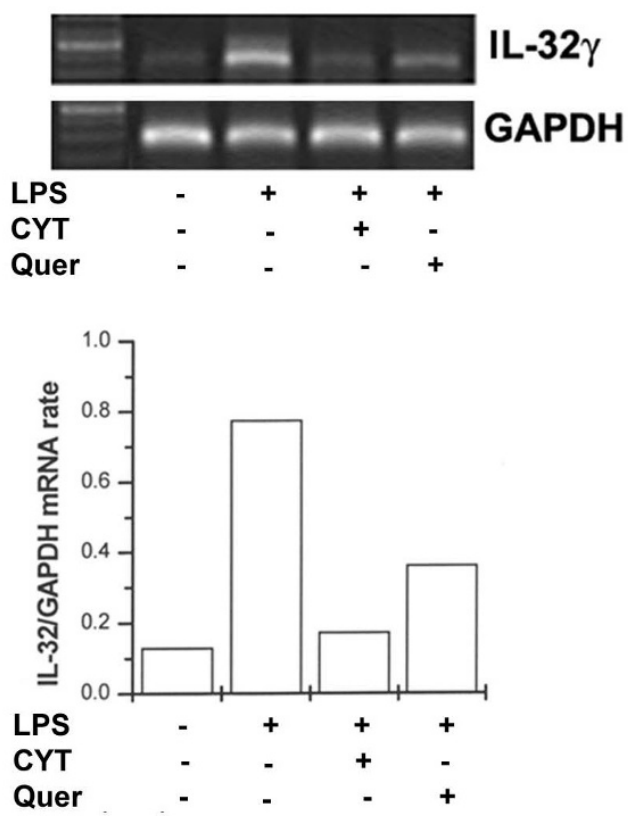

Figure 5 Effects of CYT and quercetin on LPS-induced IL-32 production. PBMCs $\left(2 \times 10^{5}\right)$ were treated with CYT, quercetin, or caspase-1 inhibitor $(10 \mu \mathrm{M})$ for $2 \mathrm{~h}$ and then stimulated with LPS $(10 \mathrm{ng} / \mathrm{ml})$ for $24 \mathrm{~h}$. Cytokine concentrations were measured in cell supernatants using the ELISA method (A). PBMCs $\left(2 \times 10^{6}\right)$ were treated with CYT $(1 \mathrm{mg} / \mathrm{ml})$ or quercetin $(0.1 \mathrm{mM})$ for $2 \mathrm{~h}$ and then stimulated with LPS $(10 \mathrm{ng} / \mathrm{ml})$ for $8 \mathrm{~h}$. Messenger RNA was measured using RT-PCR method. Results are representative of three independent experiments and band intensities correspond to levels of IL-32/GAPDH rate (B). ${ }^{*} P<0.05$, significantly different from the unstimulated cells. ${ }^{* *} P<0.05$ compared to LPS alone. Quer, quercetin.

aqueous extract of Scutellaria baicalensis has a protective effect against acrolein-induced oxidative stress in cultured human umbilical vein endothelial cells. Some studies have suggested that wogonin, isolated from $\mathrm{Scu}$ tellariae Radix, has an anti-inflammatory effect [29] and
A

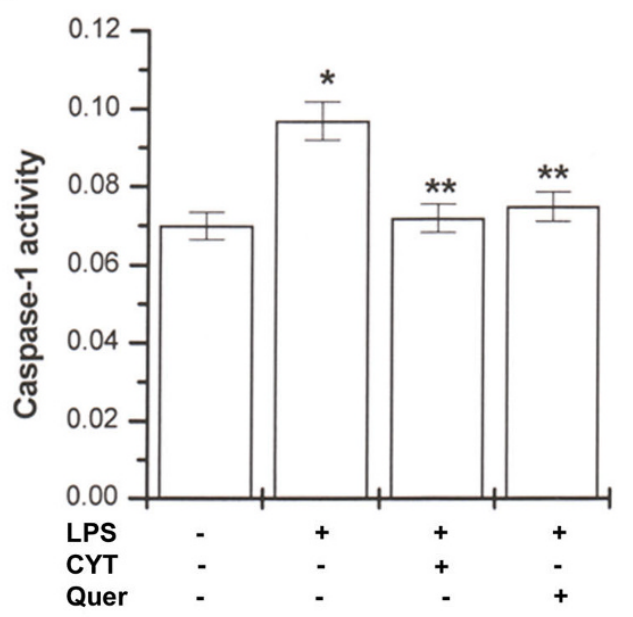

B

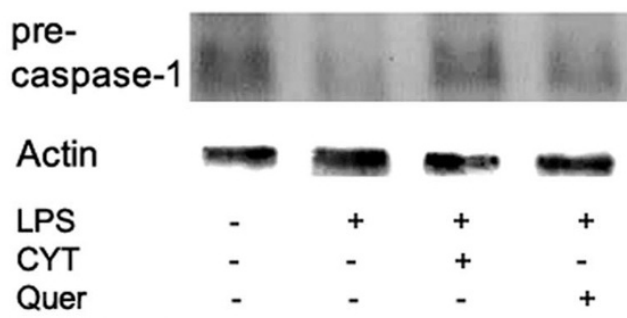

Figure 6 Effects of CYT and quercetin on LPS-induced caspase1 activation. PBMCs $\left(2 \times 10^{6} /\right.$ well) were treated with CYT $(1 \mathrm{mg} /$ $\mathrm{ml}$ ) or quercetin $(0.1 \mathrm{mM})$ for $2 \mathrm{~h}$ and then stimulated with LPS (10 $\mathrm{ng} / \mathrm{ml}$ ) for $24 \mathrm{~h}$. Caspase-1 activity was determined by a colorimetric kit using substrates (A). Caspase-1 was determined by western blot analysis (B). Data shown are the inhibition rate \pm S.D. for 10 donors, measured in duplicate. ${ }^{*} P<0.05$, significantly different from the unstimulated cells. ${ }^{*} P<0.05$ compared to LPS alone. Quer, quercetin.

triterpenes, isolated from Chrysanthemi Flos, show antiinflammatory activity against 12-O-tetradecanoylphorbol-13-acetate-induced inflammation in mice [30]. In one study, quercetin downregulated LPS-induced TNF$\alpha$ and nitric oxide production [31]. In this study, CYT and quercetin inhibited LPS-induced IL-1 $\beta$, IL- 6 , and TNF- $\alpha$ production in PBMCs. CYT and quercetin also increased $\mathrm{I} \kappa \mathrm{B}$ by preventing its degradation. The increased $\mathrm{I} \kappa \mathrm{B}$ inhibited the translocation of $\mathrm{NF}-\kappa \mathrm{B} / \mathrm{Rel}$ $A$ to the nucleus and the DNA binding activity of NF$\kappa \mathrm{B}$. CYT and quercetin also inhibited IL-32 production and caspase- 1 activation.

Cells activated by LPS produce cytokines that include interferons, IL-1, IL-6, IL-8, TNF- $\alpha$, platelet activating factors, and procoagulant tissue factors [32]. The host response to LPS involves multiple inflammatory effector mechanisms, including cytokines [33]. IL-1 is an 
endogenous pyrogen, an activating factor of lymphocyte products, and is made in many cells, especially in macrophages. It activates T-cells and B-cells, causing an inflammatory response [34]. IL-6 is a pleiotropic inflammatory cytokine produced by T-cells, monocytes, and macrophages [35]. TNF- $\alpha$ itself promotes inflammation, leukocyte infiltration, granuloma formation and tissue fibrosis and is thought to be an initiator of cytokinerelated inflammatory states by stimulating cytokine production in other types of cells [36]. Elevated levels of circulating IL-1 $\beta$, IL- 6 , IL- 8 , and TNF- $\alpha$ have been reported previously in association with various pathological states including sepsis, rheumatoid arthritis, osteoarthritis, asthma, and CI [1,2,37-39]. In our study, CYT and quercetin inhibited IL-1 $\beta$, IL-6, and TNF- $\alpha$ production and expression. Therefore, we suggest that CYT and quercetin inhibit inflammatory reaction by preventing the expression of inflammation-related genes. Further investigation is necessary to more precisely clarify the regulatory mechanisms of CYT involved in preventing LPS-induced inflammatory cytokine expression.

Activation of the NF- $\kappa \mathrm{B}$ transcription family plays an important role in inflammation because it induces transcription of proinflammatory genes [40]. This pathway is activated via cellular stimulation, most often from signals related to pathogens or stress. New therapeutic interventions aimed at limiting the activation of NF- $\kappa \mathrm{B}$ may have a beneficial effect in treating these pathological states [41]. Previously, glucocorticoids, which are frequently used in the treatment of inflammatory bowel disease and rheumatoid arthritis, were suggested to suppress NF $-\kappa \mathrm{B}$ activation. Sulfasalazine and aucubin, which are potent and specific inhibitors of NF- $\kappa \mathrm{B}$, inhibit activation without preventing AP-1 binding activity $[42,43]$. Tang et al., reported that quercetin inhibits NF$\kappa \mathrm{B}$ activation in macrophages [44]. Our results suggest that CYT and quercetin inhibit NF- $\kappa \mathrm{B}$ activation by stopping $\mathrm{I} \kappa \mathrm{B} \alpha$ degradation. As such, CYT may modulate inflammation due to infection by preventing NF- $\kappa \mathrm{B}$ activation in PBMCs.

IL-32 activates both the NF- $\kappa$ B and p38 MAPK pathways, which induce the gene transcription of proinflammatory cytokines, and it also activates proinflammatory caspases, such as caspase-1 [14]. IL-32-induced prostaglandin $E_{2}$ release is important in inflammatory responses by both mouse macrophages and human blood monocytes. Following injection of human IL-32 $\gamma$ into knee joints of naïve mice, joint swelling with pronounced influx of inflammatory cells and cartilage damage is observed [45]. IL-32 acts in a synergistic manner with the intracellular nuclear oligomerization domain (NOD)1and NOD2-specific muropeptides of peptidoglycans, resulting in release of IL-1 $\beta$ and IL-6 [14]. The synergy between IL-32 and synthetic muramyl dipeptide/NOD2 in releasing IL-6 is dependent on activation of caspase-1 and release of IL-1 $\beta$ [45]. Only the additive effects of IL32 and muropeptides were observed to cause TNF- $\alpha$ production [45]. Production of IL-32 occurs in response to influenza A virus infection via COX-2 in the inflammatory cascade [46]. Caspase-1 is involved in inflammatory responses by causing cytokine maturation [47]. In this study, CYT and quercetin inhibited LPS-induced caspase- 1 activation and IL-32 production. Caspase- 1 inhibitor also prevented IL-32 production. Therefore, we suggest that CYT inhibits IL-32 production by blocking caspase- 1 activation. We also found that caspase- 1 and IL-32 play an important role in activating NF- $\kappa$ B.

\section{Conclusion}

In conclusion, we suggest that CYT and quercetin decrease LPS-induced inflammatory cytokine production by inhibiting NF- $\kappa \mathrm{B}$ and caspase- 1 activation. CYT may be useful in the treatment of inflammatory diseases. However, its other components should be isolated and examined in additional studies to clarify whether they may also be effective in treating $\mathrm{CI}$.

\section{Abbreviations}

ABTS: 2'-azino-bis (3-ethylbenzithiazoline-6-sulfonic acid) tablet substrates; Cl: cerebral infarction; CYT: Chungsim-Yeunja-Tang; IL: interleukin; LPS: lipopolysaccharide; NF- $\kappa$ B; nuclear factor- $\kappa$ B; MTT: 3-[4, 5-Dimethylthiazole-2yl]-2, 5,-diphenyl-tetrazolium bromideand; PBMCs: peripheral blood mononuclear cells; TNF- $\alpha$ : tumor necrosis factor- $\alpha$;

\section{Acknowledgements}

This work was supported by a grant from the Kyung Hee University in 2009 (KHU-20090502).

\section{Author details}

${ }^{1}$ Biochip Research Center, Hoseo University, 165, Sechul-ri, Baebang-myun, Asan, Chungnam, 336-795, Republic of Korea. 'Department of Pharmacology, College of Oriental Medicine, Kyung Hee University, 1 Hoegi-dong, Dongdaemun-gu, Seoul, 130-701, Republic of Korea. ${ }^{3}$ Department of Mechanical System Engineering, Chonbuk National University, Jeonju, Jeonbuk, 561-756, Republic of Korea. ${ }^{4}$ Department of Internal Medicine, Pusan National University, School of Korean Medicine, Yangsan, Gyeongnam, 626-770, Republic of Korea. ${ }^{5}$ Laboratory of Cytokine Immunology, Institute of Biomedical Science and Technology, College of Medicine, Konkuk University, Seoul, 143-701, Republic of Korea.

\section{Authors' contributions}

$\mathrm{JHJ}$ and $\mathrm{CIY}$ performed the majority of the experiments and wrote the manuscript. KMH performed the ELISA. MPD and KSH provided comments on the manuscript. HJW performed sample analysis. KHM supervised the research and co-wrote the manuscript. All authors have read and approved the final version of the manuscript

\section{Competing interests}

The authors declare that they have no competing interests.

Received: 12 October 2010 Accepted: 25 November 2010 Published: 25 November 2010

\section{References}

1. Jeong HJ, Seo SY, Noh HS, Park HS, Lee JD, Kim KS, Cho KH, Kim KY, Kim HM: Regulation of $\mathrm{TH} 1 / \mathrm{TH} 2$ cytokine production by Chungsim- 
Yeunja-Tang in patients with cerebral infarction. Immunopharmacol Immunotoxicol 2003, 25:29-39.

2. Hougee S, Sanders A, Faber J, Graus YM, Van den Berg WB, Garssen J, Smit HF, Hoijer MA: Decreased pro-inflammatory cytokine production by LPS-stimulated PBMC upon in vitro incubation with the flavonoids apigenin, luteolin or chrysin, due to selective elimination of monocytes/ macrophages. Biochem Pharmacol 2005, 69:241-248.

3. Haraoui B, Pelletier JP, Cloutier JM, Faure MP, Martel-Pelletier J: Synovial membrane histology and immunopathology in rheumatoid arthritis and osteoarthritis. In vivo effects of antirheumatic drugs. Arthritis Rheum 1991, 34:153-163.

4. Siebenlist U, Franzoso G, Brown K: Structure, regulation and function of NF-kappa B. Annu Rev Cell Biol 1994, 10:405-455.

5. Baeuerie PA, Henkel T: Function and activation of NF-kB in the immune system. Annu Rev Immunol 1994, 12:141-179.

6. Kuprsh DV, Udalova IA, Turetskaya RL, Rice NR, Nedospasov SA: Conserved kappa B element located downstream of the tumor necrosis factor alpha gene: distinct NF-kappa B binding pattern and enhancer activity in LPS activated murine macrophages. Oncogene 1995, 11:97-106.

7. Galien R, Evans HF, Garcia T: Involvment of CCAAT/enhancer-binding protein and nuclear factor-kappa B binding site in interleukin- 6 promoter inhibition by estrogens. Mol Endocrinol 1996, 10:713-722.

8. Beg AA, Finco TS, Nantermet PV, Baldwin AS Jr: Tumor necrosis factor and interleukin-1 lead to phophorylation and loss of IKB: a mechanism for NF-KB activation. Mol Cell Biol 1993, 13:3301-3310.

9. Palombella V, Rando O, Goldberg A, Maniatis T: The ubiquitin-proteasome pathway is required for processing the NF-KB1 precursor protein and the activation of NF-KB. Cell 1994, 78:773-785.

10. Sarkar A, Duncan M, Hart J, Hertlein E, Guttridge DC, Wewers MD: ASC directs NF-kappaB activation by regulating receptor interacting protein-2 (RIP2) caspase-1 interactions. J Immunol 2006, 176:4979-4986.

11. Conti P, Youinou P, Theoharides TC: Modulation of autoimmunity by the latest interleukins (with special emphasis on IL-32). Autoimmun Rev 2007, 6:131-137.

12. Kim SH, Han SY, Azam T, Yoon DY, Dinarello CA: Interleukin-32: a cytokine and inducer of TNFalpha. Immunity 2005, 22:131-142.

13. Goda C, Kanaji T, Kanaji S, Tanaka G, Arima K, Ohno S, Izuhara K: Involvement of IL-32 in activation-induced cell death in T cells. Int Immunol 2006, 18:233-240

14. Netea MG, Azam T, Ferwerda G, Girardin SE, Walsh M, Park JS, Abraham E, Kim JM, Yoon DY, Dinarello CA, Kim SH: IL-32 synergizes with nucleotide oligomerization domain (NOD) 1 and NOD2 ligands for IL-1 beta and IL- 6 production through a caspase 1-dependent mechanism. Proc Natl Acad Sci USA 2005, 102:16309-16314.

15. Netea MG, Azam T, Lewis EC, Joosten LA, Wang M, Langenberg $D$, Meng $X$, Chan ED, Yoon DY, Ottenhoff T, Kim SH, Dinarello CA: Mycobacterium tuberculosis induces interleukin-32 production through a caspase-1/IL18/interferon-gamma-dependent mechanism. PLoS Med 2006, 3:e277.

16. Jung HA, Jung YJ, Yoon NY, Jeong da M, Bae HJ, Kim DW, Na DH, Choi JS: Inhibitory effects of Nelumbo nucifera leaves on rat lens aldose reductase, advanced glycation endproducts formation, and oxidative stress. Food Chem Toxicol 2008, 46:3818-3826.

17. Zhu JX, Wang Y, Kong LD, Yang C, Zhang X: Effects of Biota orientalis extract and its flavonoid constituents, quercetin and rutin on serum uric acid levels in oxonate-induced mice and xanthine dehydrogenase and xanthine oxidase activities in mouse liver. J Ethnopharmacol 2004, 93:133-140.

18. Beevi SS, Narasu ML, Gowda BB: Polyphenolics profile, antioxidant and radical scavenging activity of leaves and stem of Raphanus sativus $\mathrm{L}$. Plant Foods Hum Nutr 2010, 65:8-17.

19. Miyazawa M, Hisama M: Antimutagenic activity of flavonoids from Chrysanthemum morifolium. Biosci Biotechnol Biochem 2003, 67:2091-2099.

20. Ben Trivedi A, Kitabatake N, Doi E: Toxicity of dimethyl sulfoxide as a solvent in bioassay system with HeLa cells evaluated colorimetrically with 3-(4, 5-dimethylthiazol-2-yl)-2,5-diphenyl-tetrazolium bromide. Agric Biol Chem 1990, 54:2961-2966.

21. Jeong HJ, Na HJ, Hong SH, Kim HM: Inhibition of the stem cell factorinduced migration of mast cells by dexamethasone. Endocrinology 2003, 144:4080-4086.

22. Jeong $\mathrm{HJ}$, Um JY, Hong SH, Kim HM: Oriental medicine in cerebral infarction. In research focus on natural products and the body's immune and inflammatory systems. Edited by: Suk K. Nova Science publisher, Inc; 2007:75-105

23. Kim H, Lee E, Lim T, Jung J, Lyu Y: Inhibitory effect of Asparagus cochinchinensis on tumor necrosis factor-alpha secretion from astrocytes. Int J Immunopharmacol 1998, 20:153-162

24. Koo HN, Jeong HJ, Choi JY, Choi SD, Choi TJ, Cheon YS, Kim HM: Inhibition of tumor necrosis factor-alpha-induced apoptosis by Asparagus cochinchinensis in Hep G2 cells. J Ethnopharmacol 2000, 73:137-143.

25. Wu X, Dai H, Huang L, Gao X, Tsim KW, Tu P: A fructan, from Radix ophiopogonis, stimulates the proliferation of cultured lymphocytes: structural and functional analyses. J Nat Prod 2006, 69:1257-1260.

26. Liu CP, Tsai WJ, Lin YL, Liao JF, Chen CF, Kuo YC: The extracts from Nelumbo Nucifera suppress cell cycle progression, cytokine genes expression, and cell proliferation in human peripheral blood mononuclear cells. Life Sci 2004, 75:699-716.

27. Mukherjee PK, Saha K, Das J, Pal M, Saha BP: Studies on the antiinflammatory activity of rhizomes of Nelumbo nucifera. Planta Med 1997, 63:367-369.

28. Zhang XW, Li WF, Li WW, Ren KH, Fan CM, Chen YY, Shen YL: Protective effects of the aqueous extract of Scutellaria baicalensis against acroleininduced oxidative stress in cultured human umbilical vein endothelial cells. Pharm Biol 2010.

29. Chi YS, Lim H, Park H, Kim HP: Effects of wogonin, a plant flavone from Scutellaria radix, on skin inflammation: in vivo regulation of inflammation-associated gene expression. Biochem Pharmacol 2003, 66:1271-1278.

30. Ukiya M, Akihisa T, Yasukawa K, Kasahara Y, Kimura Y, Koike K, Nikaido T, Takido M: Constituents of compositae plants. 2. Triterpene diols, triols, and their 3-o-fatty acid esters from edible chrysanthemum flower extract and their anti-inflammatory effects. J Agric Food Chem 2001, 49:3187-3197.

31. Kumazawa $Y$, Kawaguchi $K$, Takimoto H: Immunomodulating effects of flavonoids on acute and chronic inflammatory responses caused by tumor necrosis factor alpha. Curr Pharm Des 2006, 12:4271-4279.

32. Masihi KN, Madaj K, Hintelmann H, Gast G, Kaneko Y: Down-regulation of tumor necrosis factor-alpha, moderate reduction of interleukin-1 beta, but not interleukin- 6 or interleukin-10, by glucan immunomodulators curdlan sulfate and lentinan. Int J Immunopharmacol 1997, 19:463-468.

33. Kim CH, Kim JH, Moon SJ, Chung KC, Hsu CY, Seo JT, Ahn YS: Pyrithione, a zinc ionophore, inhibits NF-kB activation. Biochem Biophys Res Commun 1999, 259:505-509.

34. Dinarello CA: Interleukin-1 and its biologically related cytokines. Adv Immunol 1989, 44:153-205.

35. Van Snick J: Interleukin-6: an overview. Annu Rev Immunol 1990, 8:253-278.

36. Baumgartner RA, Yamada K, Deramo VA, Beaven MA: Secretion of TNF- $a$ from a rat mast cell line is a brefeldin A-sensitive and a calcium/protein kinase C-regulated process. J Immunol 1994, 153:2609-2617.

37. Hammami MM, Bouchama A, Al-Sedairy S, Shail E, AlOhaly Y, Mohamed GE: Concentrations of soluble tumor necrosis factor and interleukin-6 receptors in heatstroke and heatstress. Crit Care Med 1997, 25:1314-1319.

38. Lin MT, Kao TY, Su CF, Hsu SS: Interleukin-1 beta production during the onset of heat stroke in rabbits. Neurosci Lett 1994, 174:17-20.

39. Jeong HJ, Kim BS, Oh JG, Kim KS, Kim HM: Regulatory effect of cytokine production in asthma patients by SOOJI CHIM (Koryo Hand Acupuncture Therapy). Immunopharmacol Immunotoxicol 2002, 24:265-274.

40. Jobin C, Bradham CA, Russo MP, Juma B, Narula AS, Brenner DA, Sartor RB: Curcumin blocks cytokine-mediated NF-kappa B activation and proinflammatory gene expression by inhibiting inhibitory factor I-kappa B kinase activity. J Immunol 1999, 63:3474-3483.

41. Bouchama A, Knochel JP: Heat stroke. N Engl J Med 2002, 346:1978-1988.

42. Christian W, Susanne L, Guido A, Roland MS: Sulfasalazine: potent and specific inhibitor of nuclear factor kappa B. J Clin Invest 1998, 101:1163-1174.

43. Jeong HJ, Koo HN, Na HJ, Kim MS, Hong SH, Eom JW, Kim KS, Shin TY, Kim HM: Inhibition of TNF-alpha and IL-6 production by Aucubin through blockade of NF-kappaB activation RBL-2H3 mast cells. Cytokine 2002, 18:252-259.

44. Tang D, Kang R, Xiao W, Zhang H, Lotze MT, Wang H, Xiao X: Quercetin prevents LPS-induced high-mobility group box 1 release and proinflammatory function. Am J Respir Cell Mol Biol 2009, 41:651-660. 
45. Dinarello CA, Kim SH: IL-32, a novel cytokine with a possible role in disease. Ann Rheum Dis 2006, 65:61-64.

46. Li W, Liu Y, Mukhtar MM, Gong R, Pan Y, Rasool ST, Gao Y, Kang L, Hao Q, Peng G, Chen Y, Chen X, WU J, Zhu Y: Activation of interleukin-32 proinflammatory pathway in response to influenza A virus infection. PLOS ONE 2008, 3:e1985.

47. Howley B, Fearnhead HO: Caspases as therapeutic targets. J Cell Mol Med 2008, 12:1502-1516.

doi:10.1186/1742-2094-7-85

Cite this article as: Jeong et al:: Chungsim-Yeunja-Tang decreases the inflammatory response in peripheral blood mononuclear cells from patients with cerebral infarction through an NF- $\kappa$ B dependent mechanism. Journal of Neuroinflammation 2010 7:85.

Submit your next manuscript to BioMed Central and take full advantage of:

- Convenient online submission

- Thorough peer review

- No space constraints or color figure charges

- Immediate publication on acceptance

- Inclusion in PubMed, CAS, Scopus and Google Scholar

- Research which is freely available for redistribution

Submit your manuscript at www.biomedcentral.com/submit
C Biomed Central 